\title{
Émile Verhaeren, Poésie Complète 7. Les Visages de la Vie, Les Douze Mois, Petites Légendes
}

\section{Maria Emanuela Raffi}

\section{(2) OpenEdition}

1 Journals

\section{Edizione digitale}

URL: http://journals.openedition.org/studifrancesi/7006

DOI: $10.4000 /$ studifrancesi.7006

ISSN: 2421-5856

\section{Editore}

Rosenberg \& Sellier

\section{Edizione cartacea}

Data di pubblicazione: 1 septembre 2010

Paginazione: 400

ISSN: 0039-2944

\section{Notizia bibliografica digitale}

Maria Emanuela Raffi, «Émile Verhaeren, Poésie Complète 7. Les Visages de la Vie, Les Douze Mois,

Petites Légendes», Studi Francesi [Online], 161 (LIV | II) | 2010, online dal 30 novembre 2015, consultato il 10 janvier 2021. URL: http://journals.openedition.org/studifrancesi/7006 ; DOI: https://doi.org/ 10.4000/studifrancesi.7006

Questo documento è stato generato automaticamente il 10 janvier 2021.

\section{(c) $(7)(\mathrm{BY}$}

Studi Francesi è distribuita con Licenza Creative Commons Attribuzione - Non commerciale - Non opere derivate 4.0 Internazionale. 


\title{
Émile Verhaeren, Poésie Complète 7. Les Visages de la Vie, Les Douze Mois, Petites Légendes
}

\author{
Maria Emanuela Raffi
}

\section{NOTIZIA}

Émile Verhaeren, Poésie Complète 7. Les Visages de la Vie, Les Douze Mois, Petites Légendes, édition critique établie par Michel OTTEN, Introduction par Vic NACHTERGAELE, Bruxelles, AML Éditions, 2009, pp. 407.

$1 \quad$ Les visages de la Vie (1899) è la raccolta principale di questo settimo volume dell'opera poetica di Verhaeren. Definita da Nachtergaele «une longue méditation de l'homme moderne» alla soglia del nuovo secolo, essa mostra nelle diverse poesie che la compongono un movimento generale di perdita di individualità in un "Tout" dai contorni indefiniti e mutevoli, formato dalle "forces unanimes" della vita. Anche il poeta, da uomo moderno, non può che uscire da se stesso e partecipare ad un'avventura che non va verso nuove scoperte, ma verso la dissoluzione nell'oceano, ultima fusione e «métamorphose dans le grand Tout». Les Douze Mois (1895, con il titolo di Almanach), sorta di almanacco di canzoni popolari modulate sui dodici mesi dell'anno e Les Petites Légendes (1900), divise fra «le fantastique et les histoires bon enfant» completano il volume. 